\title{
A Multiplex Real-Time PCR Assay for the Detection of Puccinia horiana and $P$. chrysanthemi on Chrysanthemum
}

Jill E. Demers, Jo Anne Crouch, and Lisa A. Castlebury, Systematic Mycology and Microbiology Laboratory, United States Department of Agriculture, Agricultural Research Service, Beltsville, MD 20705

\begin{abstract}
Demers, J. E., Crouch, J. A., and Castlebury, L. A. 2015. A multiplex real-time PCR assay for the detection of Puccinia horiana and P. chrysanthemi on chrysanthemum. Plant Dis. 99:195-200.

Puccinia horiana, the cause of chrysanthemum white rust, is a regulated fungal plant pathogen in the United States, while P. chrysanthemi, the cause of chrysanthemum brown rust, is a widespread but less destructive pathogen. Accurate identification is essential to enforce quarantine measures, but the two species cannot be differentiated visually in the absence of mature spores or symptoms. A multiplex realtime PCR assay was developed to detect and discriminate between $P$. chrysanthemi and $P$. horiana. Species-specific hydrolysis probes labeled with different fluorescent dyes were designed based on the rDNA

herbarium specimens of chrysanthemum rust were tested with the assay with results confirmed using spore morphology. $P$. horiana and $P$. chrysanthemi were accurately detected from all fresh samples, and as little as $1 \mathrm{pg}$ of template DNA was reproducibly detected. Of the herbarium specimens, $99 \%$ were positive for at least one species using the multiplex assay with $7 \%$ positive for both species. This multiplex assay can discriminate between $P$. chrysanthemi and $P$. horiana and provides an additional tool for identification of $P$. horiana to ensure appropriate application of quarantine measures.
\end{abstract} internal transcribed spacer region. Seven fresh samples and 270
Cultivated chrysanthemum (Chrysanthemum $\times$ morifolium Ramat.) is widely traded on both local and international scales, with annual wholesale production in the United States alone valued at $\$ 145$ million (22). Chrysanthemum plants are susceptible to a number of diseases that affect production yield and value. One of the most important diseases of chrysanthemum is white rust, caused by Puccinia horiana Henn. (Pucciniales), which is subject to quarantine and eradication in several countries, including the United States. The symptoms of white rust include chlorotic spots on the upper surface of the leaves, pustule formation mainly on the underside of the leaf (Fig. 1), and defoliation. Infection of chrysanthemum by $P$. horiana can be highly destructive, as 80 to $100 \%$ of plants can be infected during outbreaks for some susceptible cultivars $(5,13)$. Furthermore, quarantine actions on infected plants can lead to complete crop loss. Another disease of chrysanthemum is brown rust, caused by Puccinia chrysanthemi Roze. In contrast with the extensive destruction caused by $P$. horiana, infection by $P$. chrysanthemi damages the cosmetic value of infected plants, affecting their marketability but only occasionally causing serious yield losses (20). Brown rust disease has been present in the United States for over 100 years (3) and is not currently regulated.

$P$. chrysanthemi and $P$. horiana can be distinguished by spore morphology (Fig. 1). P. horiana produces hyaline to pale yellow

Corresponding author: L. Castlebury,

E-mail: Lisa.Castlebury@ars.usda.gov

* The $e$-Xtra logo stands for "electronic extra" and indicates that a supplementary table and two supplementary figures are available online.

Mention of trade names or commercial products in this publication is solely for the purpose of providing specific information and does not imply recommendation or endorsement by the United States Department of Agriculture. USDA is an equal opportunity provider and employer.

Accepted for publication 28 August 2014

http://dx.doi.org/10.1094/PDIS-06-14-0632-RE

This article is in the public domain and not copyrightable. It may be freely reprinted with customary crediting of the source. The American Phytopathological Society, 2015. teliospores that are 30 to $45 \times 13$ to $17 \mu \mathrm{m}$ (14) and no urediniospores. $P$. chrysanthemi produces round, cinnamon-brown urediniospores that are 10 to $25 \times 25$ to $34 \mu \mathrm{m}$ and dark brown teliospores that are 18 to $28 \times 34$ to $57 \mu \mathrm{m}$ (4). The symptoms of brown rust and white rust are difficult to distinguish, as both cause chlorotic spots on the upper leaf surface and defoliation. $P$. horiana forms telia that are white to light brown due to the presence of hyaline teliospores and basidiospores, hence the name white rust. $P$. chrysanthemi produces brown uredinia, so it is known as brown rust. However, pustules caused by $P$. horiana may become darker with age and look similar to brown rust. Under certain conditions, $P$. chrysanthemi may form black telia, although these have been reported mostly in Japan, where the disease is known as black rust $(4,15)$. Visual identification of either fungus is not possible in the latent stages of disease without sporulation $(7,8,24)$ and for some resistant chrysanthemum cultivars on which sporulation does not occur (11).

In addition to $P$. chrysanthemi and $P$. horiana, the only other rust fungus described on Chrysanthemum $\times$ morifolium is Phakopsora artemisiae Hirats. f. (= Uredo autumnalis), reported exclusively in Asia (12). Ph. artemisiae is easily identified by its distinctive subepidermal teliospores and yellow urediniospores 22 to $30 \times 17$ to $25 \mu \mathrm{m}$ in size. One more rust fungus, Phakopsora compositarum, has been reported on $C$. indicum (12) but is morphologically very similar to Ph. artemisiae and possibly synonymous. Several other rust fungi have been reported on Chrysanthemum, including Puccinia aecidii-leucanthemi, $P$. heeringiana, $P$. leucanthemi, $P$. pyrethri, and $P$. tanaceti $(12,20)$. However, Chrysanthemum and related genera in the Anthemideae have undergone numerous taxonomic revisions $(16,25)$, and these rust fungi do not affect plants in the genus Chrysanthemum as it is currently described.

The goal of this study was to create real-time PCR assays to detect both $P$. chrysanthemi and $P$. horiana to aid in the diagnosis and discrimination of these two chrysanthemum diseases. PCR-based detection assays have been previously developed for $P$. horiana using conventional PCR and real-time PCR $(1,19)$. These real-time assays were shown to detect as little as $1 \mathrm{pg}$ (19) or $5 \mathrm{fg}$ (1) of $P$. horiana DNA and did not produce false positives with $P$. chrysanthemi, although both studies only included a single sample of $P$. chrysanthemi. The objective of this study was to develop a multiplex real-time PCR assay to simultaneously detect and discriminate 
between $P$. horiana and $P$. chrysanthemi in fresh or dried specimens of chrysanthemum.

\section{Materials and Methods}

Fungal specimens and DNA extraction. Specimens of rust fungi used in this study are listed in Supplementary Table 1 and consisted of 187 herbarium accessions of Puccinia chrysanthemi and 83 accessions of $P$. horiana on Chrysanthemum spp. These collections were made from 30 countries between 1889 and 2004. Ten specimens of Ph. artemisiae, 18 additional Puccinia spp. on related host genera, and five non-target Puccinia spp. were also included. Four fresh specimens of $P$. chrysanthemi were collected in the mid-Atlantic region of the United States in October and November 2013 and identified microscopically using a Zeiss Axioplan2 microscope with measurements made using Zeiss AxioVision 4.8.2 software. Asymptomatic leaves were collected from two Chrysanthemum sp. plants during August and November 2013, and leaves with spots but no sporulation were collected from three plants.
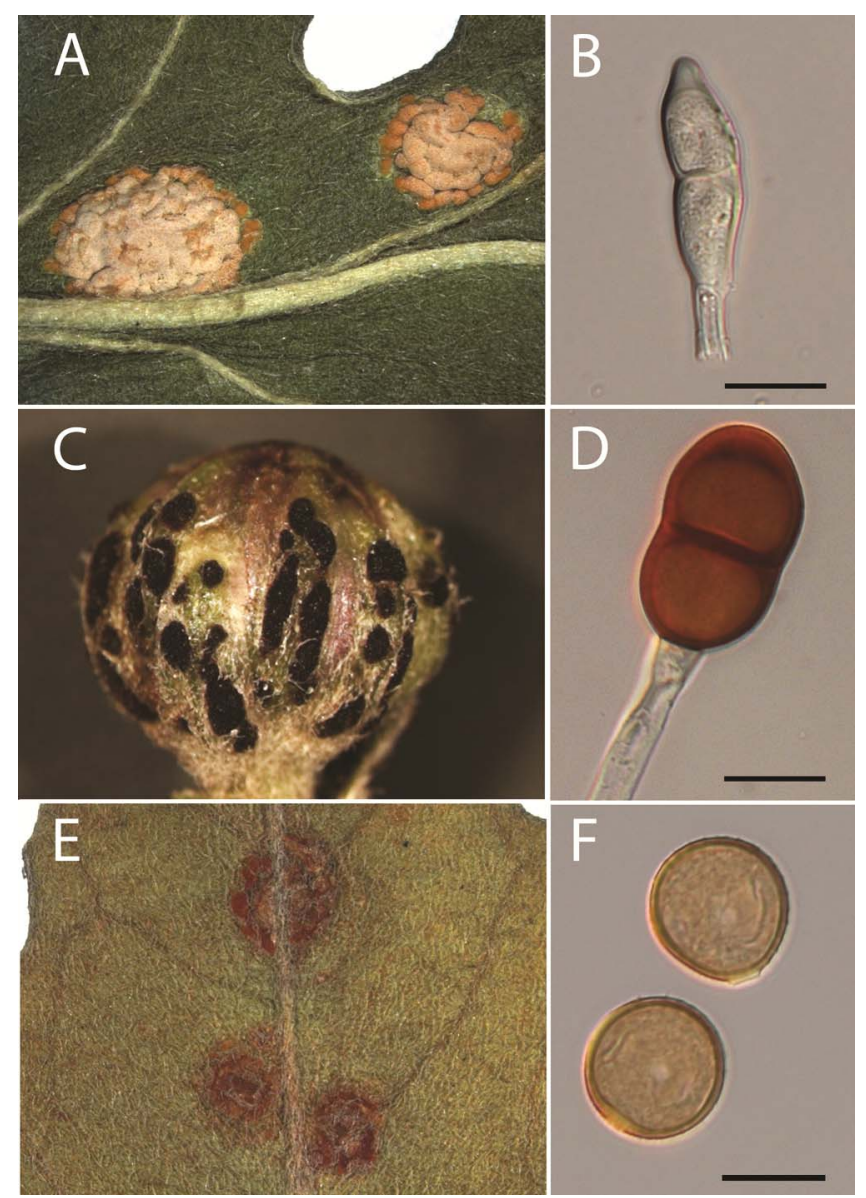

Fig. 1. Sori and spores of Puccinia horiana and $P$. chrysanthemi. A, P. horiana telia; B, P. horiana teliospore; C, P. chrysanthemi telia; D, P. chrysanthemi teliospore; E, P. chrysanthemi uredinia; F, P. chrysanthemi urediniospores. Scale bars $=20 \mu \mathrm{m}$.
To extract fungal genomic DNA, a small piece of leaf tissue with sori (approximately 0.25 to $1 \mathrm{~cm}^{2}$ ) was excised and manually ground using a micropestle in a $1.5-\mathrm{ml}$ microcentrifuge tube with $0.5 \mathrm{~mm}$ diameter glass beads (BioSpec Products, Bartlesville, OK). Ground tissue was incubated at $55^{\circ} \mathrm{C}$ overnight in DNA extraction buffer AP1 from the DNeasy Plant Mini kit (QIAGEN, Gaithersburg, MD) with $400 \mu \mathrm{g}$ RNase. The remaining steps of the extraction were carried out according to the manufacturer's instructions using the QIAcube automated sample prep machine (QIAGEN), and DNA was eluted in $100 \mu \mathrm{l}$ buffer. DNA was extracted from asymptomatic leaves with the same method using approximately $2 \mathrm{~cm}^{2}$ leaf material. For the fresh $P$. chrysanthemi specimen BPI 892937, which was used as a positive control, telia were scraped off of the leaves to minimize the amount of host DNA in the sample. Telia were ground in liquid nitrogen and DNA was extracted using the OmniPrep kit according to the manufacturer's instructions (G-Biosciences, St. Louis, MO). DNA was further purified using the Genomic DNA Clean and Concentrator kit (Zymo Research, Irvine, CA). DNA from fresh $P$. horiana specimens was provided by Doug Luster, from $P$. horiana spores harvested from infected chrysanthemum plants grown in containment at the USDA-ARS, Ft. Detrick, MD facility. DNA concentrations used for real-time PCR standard curves were measured using the Qubit dsDNA assay (Life Technologies, Grand Island, NY).

Real-time PCR assay development. PCR primers and probes for real-time PCR (Table 1) were developed using the software Beacon Designer 8.0 (PREMIER Biosoft, Palo Alto, CA) based on $P$. chrysanthemi isolate R81G-10 rDNA internal transcribed spacer (ITS) sequence (GenBank accession no. EU014038) (1) and $P$. horiana isolate $\mathrm{Ph} 308$ ITS sequence (EU013968) (1). ITS1 sequences from $P$. chrysanthemi (EU014034 to EU014038, EU400585, HQ201314 to HQ201322), P. horiana (EU013968, EU013972, EU013976, EU013999, EU014001, and EU014030), $P$. tanaceti (HQ201323 to HQ201325), and an unnamed Puccinia sp. from Chrysanthemum sp. (HQ201328 to HQ201331) were aligned using CLC Genomics Workbench 6.0.5 (CLC bio, Cambridge, MA), and hydrolysis probes were designed that bind to regions specific to $P$. chrysanthemi or $P$. horiana. Multiple ITS sequences have been reported in $P$. horiana (2), so primer binding sites were chosen that are present in all previously sequenced ITS clones. On the $5^{\prime}$ end, the $P$. chrysanthemi CBR1 probe was labeled with 6carboxyfluorescein (6-FAM) fluorescent dye and the $P$. horiana CWR2 probe was labeled with hexachloro-fluorescein (HEX) fluorescent dye. Both probes were labeled with Black Hole Quencher 1 on the $3^{\prime}$ end (Sigma-Aldrich, Saint Louis, MO) and both contained four locked nucleic acids, which are bases with a modified backbone that increase probe specificity. A previously developed real-time PCR diagnostic assay for P. horiana (1) was also tested, using the primer pair $\mathrm{Ph} 263 \mathrm{~F} / \mathrm{Ph} 264 \mathrm{R}$ and the probe $\mathrm{Ph} 706$, labeled with $5^{\prime} \mathrm{HEX}$, an internal ZEN quencher, and a $3^{\prime}$ Iowa Black quencher. An additional real-time PCR assay was designed for an unnamed Puccinia sp. reported by Alaei et al. (1) on specimens of Artemisia tridentata and Chrysanthemum sp. based on the ITS1 region (HQ201331) and used to screen all samples. Primers and probes were synthesized by Integrated DNA Technologies (Coralville, IA).

Real-time PCR reaction mixtures contained 1X LightCycler 480 master mix (Roche, Indianapolis, IN), $1.0 \mu \mathrm{M}$ of each primer, and

Table 1. Sequences of the primers and probes for real-time PCR amplification, with locked nucleic acids in the probes indicated with capital letters

\begin{tabular}{lll}
\hline Primers and probes & & \\
\hline Puccinia chrysanthemi & & TGGCTCAAATTTTATTAATTTAAAC \\
Forward primer & CBR1F & GTTGCTTTTACTTGATTGAAA \\
Reverse primer & CBR1R & $\left(5^{\prime}-6\right.$ FAM) tgaTtgTatGacCgcc $\left(3^{\prime}\right.$-BHQ1) \\
Probe & CBR1 & GCAGAAGGATCATTATTAAAAGA \\
$\begin{array}{l}\text { Puccinia horiana } \\
\text { Forward primer }\end{array}$ & CWR2F & GGGTAATGTAACATTTCTTAGTAAA \\
Reverse primer & CWR2R & $\left(5^{\prime}\right.$-HEX) actTtaTtgTggCttgacc (3'-BHQ1) \\
\hline
\end{tabular}


$0.2 \mu \mathrm{M}$ probe, in $24 \mu \mathrm{l}$ total volume. All reactions were replicated at least three times. Amplification was performed in white 96 -well plates (Roche) in a LightCycler 480 II (Roche). The reaction cycle consisted of $95^{\circ} \mathrm{C}$ for $5 \mathrm{~min}$ followed by 55 cycles of $95^{\circ} \mathrm{C}$ for $10 \mathrm{~s}$ and the annealing temperature for $20 \mathrm{~s}$, followed by $40^{\circ} \mathrm{C}$ for $30 \mathrm{~s}$, with the annealing temperatures 50,55 , and $60^{\circ} \mathrm{C}$ tested and $55^{\circ} \mathrm{C}$ selected as optimal. Reaction threshold values were calculated with the second derivative method using Roche LightCycler 480 software (version 1.50.39). Assay efficiencies were calculated by constructing standard curves from 10-fold DNA dilutions (10 ng to $1 \times$ $10^{-4} \mathrm{ng}$ ) from the DNA of $P$. chrysanthemi BPI 892937 or $P$. horiana specimen CT11-4.

All samples were tested using the $P$. chrysanthemi and $P$. horiana $\mathrm{CBR} 1$ and CWR2 real-time assays in combination. Duplexed CBR1/CWR2 reaction conditions were similar to those used for the single assay reactions, except that the reaction mixture consisted of $1 \times$ LightCycler 480 master mix, $1.0 \mu \mathrm{M}$ of each of the four primers, $0.2 \mu \mathrm{M}$ of each probe, and $1 \mu$ l undiluted DNA in a $12 \mu \mathrm{l}$ reaction. All sets of reactions included a water-only negative control and positive controls of $1 \mathrm{ng}$ of DNA from $P$. chrysanthemi BPI 892937 DNA and $1 \mathrm{ng}$ of DNA from $P$. horiana CT11-4. For the herbarium DNA, different DNA dilutions $(7 \times, 4 \times, 1 \times, 1: 10$, and 1:100 dilutions) were tested using three $P$. chrysanthemi specimens identified in preliminary tests as having high-, medium-, and lowquality DNA extracts based on crossing point $(\mathrm{Cp})$ values for the CBR1 assay. One microliter of DNA extract was used for the freshly collected samples and asymptomatic leaves. The ability of the multiplex assay to detect mixed infections was tested on mixed DNA consisting of $1 \mathrm{ng}$ DNA from $P$. chrysanthemi BPI 892937 and $1 \mathrm{ng}$ DNA from $P$. horiana CT11-4.

\section{Results}

Assay development, amplification efficiency, and sensitivity limits. Real-time PCR hydrolysis probes for simultaneous detection of $P$. chrysanthemi and P. horiana, CBR1 and CWR2, were designed from the ITS1 regions of $P$. chrysanthemi isolate R81G10 (EU014038) and P. horiana Ph308 (EU013968) (Fig. 2). The amplicon for the $P$. chrysanthemi CBR1 assay was $88 \mathrm{bp}$ and the amplicon for the $P$. horiana $\mathrm{CWR} 2$ assay was $165 \mathrm{bp}$. Relative to the ITS sequence of $P$. horiana Ph308, 27 SNPs were situated in the $P$. chrysanthemi primers and probes (Fig. 2; forward primer $\mathrm{CBR} 1 \mathrm{~F}=11$; reverse primer $\mathrm{CBR} 1 \mathrm{R}=5$; probe $\mathrm{CBR} 1=11$ ). Relative to the ITS sequence of $P$. chrysanthemi isolate R81G-10, 20 SNPs were situated in the $P$. horiana primers and probes (Fig. 2; forward primer CWR1F = 3; reverse primer CWR1R = 12; probe CWR1 = 5). BLASTn searches using the probe sequences as a query of NCBI GenBank showed that $P$. chrysanthemi sequences were the only fungal or plant sequences in GenBank with $100 \%$ identity to the probe CBR1 and the only close match in the Pucciniales to CBR1. The only matches for the sequence of the probe CWR2 were P. horiana and Puccinia boroniae, found only in Australia on Boronia spp., which does not have a sequence matching the CWR2R primer binding site.

Assays were tested with annealing temperatures at 50, 55, and $60^{\circ} \mathrm{C}$. Fifty-five degrees was chosen as the best temperature to combine the two assays, as DNA amplified at lower cycle numbers with the $\mathrm{CBR} 1$ assay at 50 and $55^{\circ} \mathrm{C}$ than at $60^{\circ} \mathrm{C}$, but more effi- cient reactions occurred for the $\mathrm{CWR} 2$ assay at 55 and $60^{\circ} \mathrm{C}$ than at $50^{\circ} \mathrm{C}$. Standard curves at $55^{\circ} \mathrm{C}$ were linear for $10 \mathrm{ng}$ to $1 \times 10^{-3}$ ng for both assays $\left(P\right.$. chrysanthemi $\mathrm{r}^{2}=0.991 ; P$. horiana $\mathrm{r}^{2}=$ 0.985; Fig. 3). Crossing point (Cp) values for the $P$. chrysanthemi CBR1 assay ranged from $21.52(10 \mathrm{ng})$ to $39.67(1 \mathrm{pg})$, while $\mathrm{Cp}$ values for the $P$. horiana CWR2 assay ranged from $23.9(10 \mathrm{ng})$ to $40.2(1 \mathrm{pg})$. Amplification also occurred with $1 \times 10^{-4} \mathrm{ng}$ of DNA for both assays, but $\mathrm{Cp}$ values were not consistent across replicates. Multiplex CBR1/CWR2 reactions containing the same amount of template DNA yielded similar $\mathrm{Cp}$ values as for the individual assays (Fig. 3) (Wilcoxon rank sum test, $P=0.37$ ). For $1 \mathrm{ng}$ of template DNA, Cp values for CBR1 and CBR1/CWR2 were respectively 25.62 and 26.53, and values for CWR2 and CBR1/CWR2 were respectively 27.65 and 27.45. A previously published real-time assay for $P$. horiana (1) was tested in a multiplex reaction in conjunction with the CBR1 assay; however, late cycle low fluorescence levels barely detectable above the baseline were observed (Supplementary Fig. 1). An additional probe for P. horiana detection designed for the same region but with a higher melting point also generated low fluorescence and late cycle results.

The ability of the CBR1/CWR2 assays to detect mixed infections was tested by mixing $1 \mathrm{ng}$ of pure DNA each from $P$. chrysanthemi BPI 892937 and $P$. horiana CT11-4. In the multiplex CBR1/CWR2 reaction containing both BPI 892937 and CT11-4 DNA, detection of $P$. chrysanthemi BPI 892937 was almost identical (Wilcoxon rank sum test, $P=0.1$ ) to detection achieved from 1 ng of BPI 892937 DNA alone (Cp = 26.70 for only BPI 892937 DNA, $\mathrm{Cp}=28.08$ for BPI 892937 DNA mixed with CT11-4 DNA), but amplification of CT11-4 produced lower fluorescence levels than with $1 \mathrm{ng}$ of $P$. horiana DNA alone, although with similar $\mathrm{Cp}$ values $(\mathrm{Cp}=28.50$ for only CT11-4 DNA, $\mathrm{Cp}=28.39$ for CT11-4 DNA mixed with BPI 892937 DNA; Supplementary Fig. 2) (Wilcoxon rank sum test, $P=0.7$ ).

In addition to the $P$. chrysanthemi and $P$. horiana samples used for standard curve generation, the multiplex CBR1/CWR2 assay was tested using sori from three recently collected $P$. chrysanthemi samples and one recently collected $P$. horiana sample. In all cases, the target fungi were detected using the CBR1/CWR2 assay, with $\mathrm{Cp}$ values for the $P$. chrysanthemi samples between 26 and 29 cycles, corresponding to approximately 1 to $5 \mathrm{ng} / \mu \mathrm{l}$ of $P$. chrysanthemi DNA extracted per sample, and a $\mathrm{Cp}$ value of 30 cycles for a leaf infected with $P$. horiana, corresponding to $0.2 \mathrm{ng} / \mu \mathrm{l}$ of extracted $P$. horiana DNA. Positive results were obtained with the CBR1/CWR2 assay for a fresh sample of $P$. horiana extracted from spores, and the results were similar for those obtained for the control sample $P$. horiana CT11-4. The assay was negative for leaves collected from two asymptomatic chrysanthemum plants. Leaves from three chrysanthemum plants with leaf spots but no obvious signs of Puccinia species were tested, and one plant was positive for $P$. chrysanthemi, with $0.04 \mathrm{ng} / \mu \mathrm{l}$ of $P$. chrysanthemi DNA detected.

Specimen screening. The CBR1/CWR2 assay was used to screen 270 herbarium specimens identified as $P$. chrysanthemi or $P$. horiana. DNA was extracted from a mixture of fungal and host tissue. The optimum DNA concentration used in the assay was determined using three $P$. chrysanthemi DNA extractions, assigned to three broad quality categories (high, medium, and low quality)

Forward primer CBR1F

P. chrysanthemi EU014038

P. horiana EU013968
GCAGAAGGATCATTATTTAAACCAA-AGAGTGCACTTAATTGTGGCTCAAA-TTTTATTAATTTAAACCCCAAAC-ATTTGA GCAGAAGGATCATTATTAAAAGAACTAGAGTGCACTTTATTGTGGCTTGACCCCTTTTAAATATATCACCCAAACTATTTTA Forward primer CWR2F Probe CWR2

\section{P. chrysanthemi EU014038 \\ P. horiana EU013968}

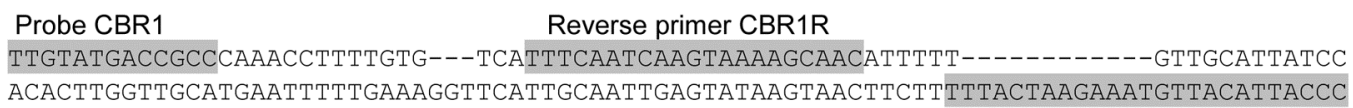

Reverse primer CWR2R

Fig. 2. Alignment of the ITS DNA sequences of Puccinia chrysanthemi and $P$. horiana showing the CBR1/CWR2 primer and probe binding sites highlighted in gray. 
based on $\mathrm{Cp}$ values with preliminary testing with the CBR1 assay, then assessed using the CBR1/CWR2 multiplex assay with $1 \mu \mathrm{l}$ of $7 \times, 4 \times, 1 \times, 1: 10$, and 1:100 dilutions. DNA concentrations above $1 \times$ did not decrease $\mathrm{Cp}$ values for low- and medium-quality DNA. High-quality DNA exhibited the lowest $C p$ values at $4 \times$ concentration, and diluting the DNA extract increased the $\mathrm{Cp}$ values for all extracts tested. All herbarium samples were therefore evaluated with $1 \mu$ of undiluted DNA extract as the template.

Ninety-four percent of the herbarium samples had $\mathrm{Cp}$ values between 27 and 45, 5\% (14 specimens) had values between 45 and
55 , and $1 \%$ ( 2 specimens) did not produce fluorescence, even after 55 cycles. Target DNA was detected in specimens dating as far back as 1889. Although the actual amount of Puccinia DNA extracted from herbarium samples could not be measured directly using spectrophotometry or fluorometry instruments due to the presence of host DNA, based on the CBR1 and CWR2 standard curves, DNA of the target pathogens was present at levels ranging from $100 \mathrm{ng}$ to $0.01 \mathrm{ng}$ in $100 \mu \mathrm{l}$ total extract. Visual examination of the two negative specimens showed signs of $P$. horiana or $P$. chrysanthemi, but only scant material was available. Amplicons
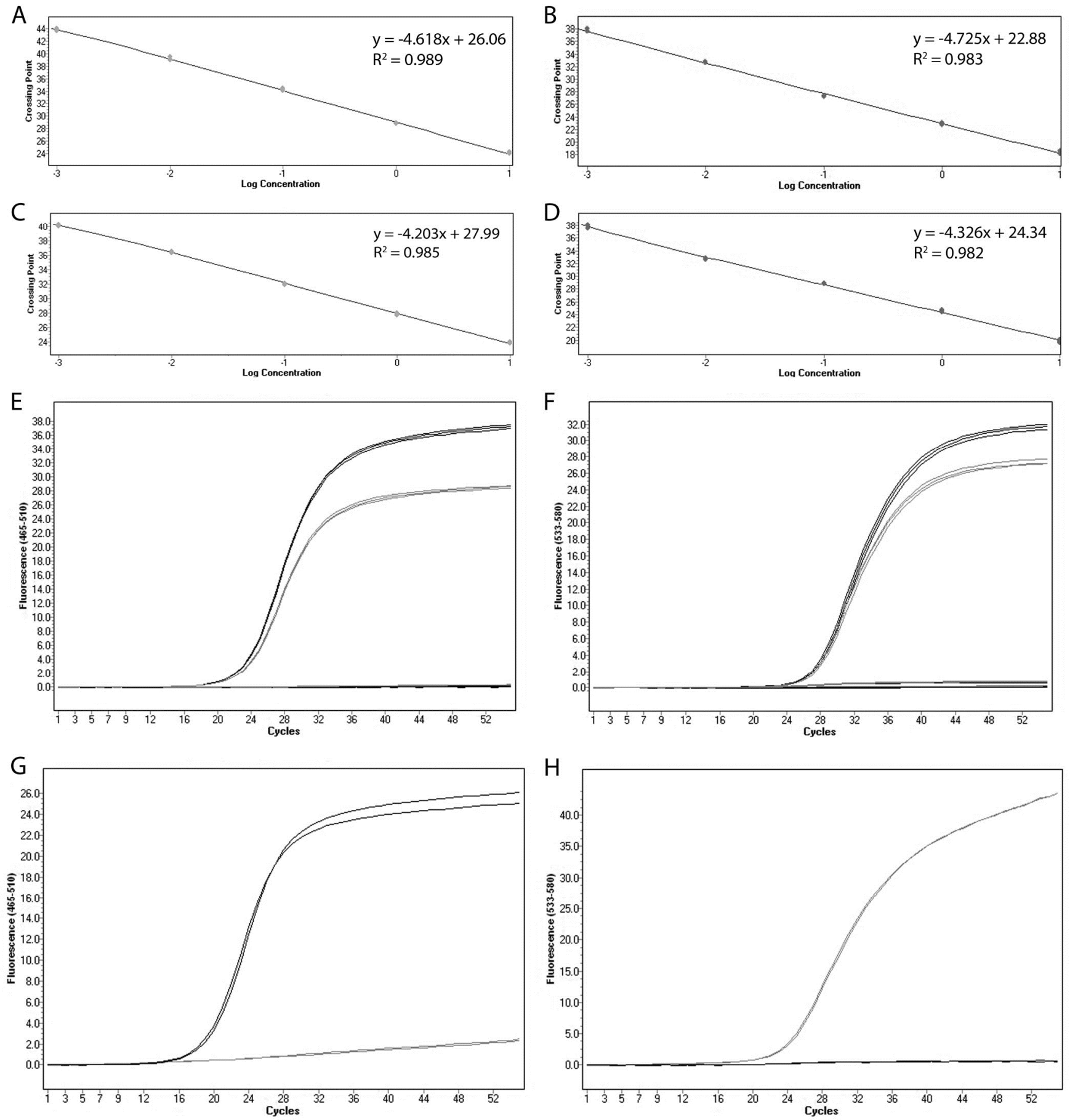

Fig. 3. Standard curves showing the correlation of the crossing point cycle with the log concentration of DNA for a 10 -fold dilution series from $10 \mathrm{ng}$ to $1 \mathrm{pg}$ of DNA for $\mathbf{A}$, Puccinia chrysanthemi using the CBR1 real-time PCR assay, B, Puccinia chrysanthemi using the CBR1/CWR2 real-time PCR assay, C, Puccinia horiana using the CWR2 real-time PCR assay, and D, Puccinia horiana using the CBR1/CWR2 real-time PCR assay. E and F, Fluorescence history of multiplex CBR1/CWR2 real-time PCR reactions (gray lines) compared to CBR1 real-time PCR reactions and CWR2 real-time PCR reactions (black lines). All reactions include $1 \mathrm{ng}$ template DNA. E, detection of the $P$. chrysanthemi CBR1 probe (6FAM). F, detection of the P. horiana CWR2 probe (HEX). $\mathbf{G}$ and $\mathbf{H}$, Fluorescence history of multiplex CBR1/CWR2 real-time PCR reactions showing G, the lack of amplification of $10 \mathrm{ng}$ of DNA of Puccinia horiana CT11-4 by the CBR1 assay and $\mathbf{H}$, the lack of amplification of $10 \mathrm{ng}$ of DNA of $P$. chrysanthemi BPI 892937 by the CWR2 assay. Gray lines: P. horiana CT11-4, black lines: P. chrysanthemi BPI 892937. 
were not observed for these two specimens using agarose gel electrophoresis.

Eight herbarium specimens morphologically identified by their original collectors as $P$. chrysanthemi and 12 specimens identified by collectors as $P$. horiana produced positive results for both the CBR 1 and CWR2 probes. Four of the eight $P$. chrysanthemi specimens and five of the $12 P$. horiana specimens where two detections were made using the CBR1/CWR2 assay were observed microscopically to be infected with both rust fungi, while only one fungus was visually observed on the other 11 samples. Three specimens originally identified as $P$. chrysanthemi produced negative results using the $P$. chrysanthemi CBR1 assay and positive results using the $P$. horiana CWR2 assay. These three specimens were confirmed microscopically as $P$. horiana.

Assay specificity. Using DNA from known samples, the $P$. horiana CWR2 assay did not detect $P$. chrysanthemi and the $P$. chrysanthemi CBR1 assay did not detect $P$. horiana, even when tested against $10 \mathrm{ng}$ of pure DNA (Fig. 3). Other species of rust fungi were tested with the multiplex CBR1/CWR2 assay, including an uncommon species known to infect Chrysanthemum (Ph. artemisiae), as well as 23 additional Puccinia spp. The P. horiana CWR2 assay produced negative results for all other tested species except $P$. artemisiicola on Artemisia campestris, P. artemisiicola on A. stolonifera, and $P$. heeringiana on Tanacetum parthenium. These three specimens were unmistakably different from $P$. horiana based on morphology, with both species producing reddish-brown telia with pale brown teliospores. The teliospores for $P$. artemisiicola were 44 to $71 \times 20$ to $33 \mu \mathrm{m}$ and teliospores for $P$. heeringiana were 43 to $59 \times 23$ to $27 \mu \mathrm{m}$, all significantly larger than $P$. horiana teliospores. The $P$. chrysanthemi CBR1 assay was negative for all other species of rust fungi when combined with the $P$. horiana CWR2 assay. Very low levels of fluorescence, slightly above the baseline, were observed for $P$. tanaceti on Tanacetum vulgare and $P$. pyrethri on Tanacetum corymbosum with the multiplex assay, although these were not observed with the $P$. chrysanthemi CBR1 assay alone. Positive results were observed from the $P$. chrysanthemi CBR1 assay alone, but not from the multiplex CBR1/CWR2 assay, for Puccinia similis on Artemisia tridentata and $A$. cana, although detection of these specimens always occurred after cycle 45 . Sequences for the $P$. similis specimens are available in NCBI GenBank (GU168942 and GU168943) and confirm they are very similar to the undescribed Puccinia species identified by Alaei et al. (1) with at least $99.6 \%$ sequence identity in the $5^{\prime}$ end of the ribosomal large $28 \mathrm{~S}$ subunit. Another real-time PCR assay, referred to as CBR2, was designed to detect this Puccinia sp. and was used to test all $P$. chrysanthemi and morphologically similar rusts. The CBR2 assay was positive for the two $P$. similis specimens but no others, including the $P$. chrysanthem $i$ samples.

\section{Discussion}

$P$. horiana is a quarantine pathogen in the United States, and accurate detection of this fungus is important for effective containment and eradication efforts. This study provides a multiplex realtime PCR assay for the simultaneous detection of $P$. chrysanthemi and $P$. horiana, the two most common rust fungi on chrysanthemum.

The multiplex CBR1/CWR2 assay was effective across a wide range of DNA concentrations and could reproducibly amplify target DNA to a lower limit of $1 \mathrm{pg}$. The CBR1/CWR2 assay compares well to the two previously published real-time PCR assays designed to detect $P$. horiana, which were reported to detect $1 \mathrm{pg}$ (19) or $5 \mathrm{fg}$ (1) of $P$. horiana DNA. In addition to detecting $P$. horiana, the CBR1/CWR2 assay also detects $P$. chrysanthemi, a common pathogen that can affect the marketability of chrysanthemums and can be confused with $P$. horiana. An assay has been published (19) that uses different primer sets to detect both $P$. chrysanthemi and $P$. horiana but, as discussed by the author, is not appropriate for a multiplex assay because the probe sequence is not speciesspecific. The multiplex assay presented here will detect both $P$. horiana and $P$. chrysanthemi in one reaction.
Identification of $P$. chrysanthemi and $P$. horiana using the realtime PCR assay provided greater accuracy and sensitivity than visual identification alone. Three specimens originally identified as $P$. chrysanthemi in herbarium materials were found to be $P$. horiana based on our real-time PCR data and subsequent morphological re-examination. The multiplex CBR1/CWR2 assay detected both $P$. chrysanthemi and $P$. horiana in the same sample for 20 of the 270 herbarium specimens tested, demonstrating that infections by both rust fungi in one plant occasionally occur. In the multiplex CBR1/CWR2 assay, fluorescence levels for the P. horiana CWR2 probe are lower when both species are present. We suggest that chrysanthemum samples that are ambiguously positive (i.e., have low fluorescence levels or amplification after cycle 40) for $P$. horiana when $P$. chrysanthemi is also detected should be verified by using each of the two assays independently. Testing multiple pustules per leaf is also recommended in case both rust species are present.

Latent infections have been reported for both $P$. chrysanthemi and $P$. horiana $(8,24)$, including systematic infection of overwintering plants by $P$. horiana (7). Our results suggest that real-time PCR can be used to detect these pathogens in the absence of sporulation. For example, the CBR1/CWR2 assay provided detection of $P$. chrysanthemi from one chrysanthemum sample exhibiting chlorotic leaf spots but lacking fungal spores. Furthermore, 11 specimens of diseased chrysanthemum, seven originally identified as $P$. horiana and four identified as $P$. chrysanthemi, generated positive assay results for both fungi, although only one fungus was observed microscopically.

$P$. chrysanthemi has undergone taxonomic changes and has at times been synonymized with morphologically similar fungi on related hosts, such as $P$. absinthii, $P$. dracunculina, $P$. tanaceti, and $P$. pyrethri (10). However, inoculation studies with $P$. chrysanthemi found that the fungus only causes disease on species of Chrysanthemum (15), and rusts on other hosts appear to be caused by other species (18). For example, a phylogenetic study by Alaei et al. (2) based on ITS sequence data showed that $P$. chrysanthemi forms a distinct clade within Puccinia, closely related to $P$. tanaceti on Tanacetum (Anthemideae) and an unnamed Puccinia sp. on Chrysanthemum sp. It is not clear if this unnamed Puccinia species causes disease on Chrysanthemum sensu stricto or on one of the chrysanthemum species now classified in a different genus in the Anthemideae, but an assay designed to detect this fungus was only positive for two specimens on Artemisia and was negative for all specimens on Chrysanthemum.

The present study used herbarium material from the U.S. National Fungus Collections, which allowed us to test specimens from a worldwide collection, likely to be representative of the genetic diversity in $P$. horiana and $P$. chrysanthemi. One hundred eighteen specimens were from Japan, the suspected origin of both $P$. horiana and $P$. chrysanthemi. The collection was also likely to be genetically diverse, as hosts included several species of Chrysanthemum and were collected from 1889 to 2004. The earliest specimen of $P$. chrysanthemi from the United States was from 1896 from the first reported outbreak in the United States in Fitchburg, MA (3). The CBR1/CWR2 assay detected each target fungus for all fresh samples and all herbarium samples, with the exception of one specimen morphologically identified as $P$. horiana and one specimen identified as $P$. chrysanthemi in which insufficient material was present to extract enough DNA for detection. The positive results obtained for this diverse collection suggest that the CBR1/CWR2 assay will work for all populations of these rust fungi.

Although using herbarium specimens allows for testing of a genetically diverse collection, DNA from herbarium specimens is often degraded and fragmented (21). Despite this degradation, DNA from herbarium material can be amplified, especially with real-time PCR, which is more sensitive and uses smaller amplicon sizes than most conventional PCR methods. For the chrysanthemum rust fungi, $\mathrm{Cp}$ values for DNA extracted from herbarium material were within the linear range of the assay but higher than 
the values obtained for fresh material (usually 30 to 45 versus 26 to 31 , respectively). Real-time PCR has been previously used with herbarium material to detect the corn rust pathogens Puccinia polysora and $P$. sorghi, (9), the turfgrass anthracnose fungus Colletotrichum cereale (6), and the causal agent of citrus bacterial canker Xanthomonas citri (17). Real-time PCR is therefore a useful method for studying herbarium collections, which can be a valuable source of information on the diversity and historical distribution of fungal species (23).

$P$. horiana is currently excluded from the United States when found on imported chrysanthemums and eradicated when found within the country. This assay can detect plants infected with $P$. horiana that need to be eradicated and help ensure that stock plants are free of $P$. horiana. The greater sensitivity and accuracy of the assay compared to visual diagnosis will furthermore be useful in detecting $P$. chrysanthemi and $P$. horiana before the onset of symptom development.

\section{Acknowledgments}

We thank Bonnie To for help with processing the chrysanthemum rust samples and assay development, Tunesha Phipps for technical support, and the U.S. National Fungus Collections. This work was funded by USDA-APHIS 2013 Farm Bill 10201 and a 2013 Friends of Agricultural Research - Beltsville student summer internship. J.E.D. is supported by a 2012 USDA-ARS Headquarters Post-doctoral Fellowship to L.A.C.

\section{Literature Cited}

1. Alaei, H., Baeyen, S., Maes, M., Höfte, M., and Heungens, K. 2009. Molecular detection of Puccinia horiana in Chrysanthemum $\times$ morifolium through conventional and real-time PCR. J. Microbiol. Meth. 76:136-145.

2. Alaei, H., De Backer, M., Nuytinck, J., Maes, M., Höfte, M., and Heungens, K. 2009. Phylogenetic relationships of Puccinia horiana and other rust pathogens of Chrysanthemum $\times$ morifolium based on rDNA ITS sequence analysis. Mycol. Res. 113:668-683.

3. Arthur, J. C. 1900. Chrysanthemum rust. Bulletin of the Indiana Agricultural Experiment Station 85:143-150.

4. Arthur, J. C. 1934. Manual of the Rusts in United States and Canada. The Science Press Printing Co., Lancaster, PA.

5. Baker, J. J. 1967. Chrysanthemum white rust in England and Wales $1963-$ 66. Plant Pathol. 16:162-166.

6. Beirn, L. A., Clarke, B. B., and Crouch, J. A. 2014. Influence of host and geographic locale on the distribution of Colletotrichum cereale lineages. PLoS One 9(5):e97706.

7. Bonde, M. R., Murphy, C. A., Bauchan, G. R., Luster, D. G., Palmer, C. L., Nester, S. E., Revell, J. M., and Berner, D. K. 2015. Evidence for systemic infection by Puccinia horiana, causal agent of chrysanthemum white rust, in chrysanthemum. Phytopathology 105:91-98.

8. Campbell, C. E., and Dimock, A. W. 1955. Temperature and the geographical distribution of chrysanthemum rust. Phytopathology 45:644-648.

9. Crouch, J. A., and Szabo, L. J. 2011. Real-time PCR detection and discrimination of the southern and common corn rust pathogens Puccinia polysora and Puccinia sorghi. Plant Dis. 95:624-632.

10. Cummins, G. B. 1978. Rust Fungi on Legumes and Composites in North America. University of Arizona Press, Tucson, AZ

11. De Jong, J., and Rademaker, W. 1986. The reaction of Chrysanthemum cultivars to Puccinia horiana and the inheritance of resistance. Euphytica 35:945-952.

12. Farr, D. F., and Rossman, A. Y. (Current) Fungal Databases, Systematic Mycology and Microbiology Laboratory, ARS, USDA. Online: http://nt.arsgrin.gov/fungaldatabases/.

13. Göre, M. E. 2008. White rust outbreaks on chrysanthemum caused by Puccinia horiana in Turkey. Plant Pathol. 57:786.

14. Hennings, P. 1901. Einige neue japanische Uredineen. Hedwigia 40:25-26.

15. Hiratsuka, N. 1957. Three species of chrysanthemum rusts in Japan and its neighbouring districts. Beihefte zur Sydowia, Annales Mycologici, Series II 1:34-44.

16. Liu, P. L., Wan, Q., Guo, Y. P., Yang, J., and Rao, G. Y. 2012. Phylogeny of the genus Chrysanthemum L.: Evidence from single-copy nuclear gene and chloroplast DNA sequences. PloS ONE 7:e48970.

17. Marvrodieva, V., Levy, L., Gabriel, D. W. 2004. Improved sampling methods for real-time polymerase chain reaction diagnosis of citrus canker from field samples. Phytopathology 94:61-68.

18. Newcombe, G. 2003. Puccinia tanaceti: specialist or generalist? Mycol Res. 107:797-802.

19. Pedley, K. F. 2009. PCR-based assays for the detection of Puccinia horiana on chrysanthemums. Plant Dis. 93:1252-1258.

20. Punithalingam, E. 1968. Puccinia chrysanthemi. CMI Descriptions of Pathogenic Fungi and Bacteria. No. 175.

21. Staats, M., Cuenca, A., Richardson, J. E., Vrielink-van Ginkel, R., Petersen, G., Seberg, O., and Bakker, F. T. 2011. DNA damage in plant herbarium tissue. PLoS ONE 6:e28448.

22. USDA National Agricultural Statistics Service. 2009. Census of Horticultural Specialties. Vol. 3. Part 3.

23. Verkley, G. J. M, Rossman, A., and Crouch, J. A. 2013. The role of herbaria and culture collections. In: The Mycota VII: Systematics and Evolution, Part B. D. J. McLaughlin, M. Blackwell, and J. W. Spatafora, eds. In press.

24. Zandvoort, R., Groenewegen, C. A., and Zadoks, J. C. 1968. On the incubation period of Puccinia horiana. Neth. J. Pl. Path. 74:128-130.

25. Zhao, H. B., Chen, F. D., Chen, S. M., Wu, G. S., and Guo, W. M. 2010 Molecular phylogeny of Chrysanthemum, Ajania and its allies (Anthemideae, Asteraceae) as inferred from nuclear ribosomal ITS and chloroplast trnL-F IGS sequences. Plant Syst. Evol. 284:153-169. 